\title{
LEGAL CONTROL OF DISCRETIONARY POWERS IN GHANA: LESSONS FROM ENGLISH ADMINISTRATIVE LAW THEORY
}

\author{
Kwadwo B. MENSAH \\ Department of Economics and Business Studies \\ University of Cape-Coast \\ CAPE-COAST \\ GHANA
}

\section{SUMMARY}

This paper develops along the following line. First, we shall attempt to explain what discretion is, why it has become very important in the modern administrative state, and the dangers that it poses in a democratic legal system. It then looks at the problems which have to be faced in justifying judicial review of discretion. It takes an in depth analysis of legal liberalism and functionalism. Armed with these 'lenses', it attempts to explain the theoretical basis of two important Ghanaian cases, Re Akoto', and People's Popular Party $v$ Attorney General $(P P P \vee A G)^{2}$. It examines the provisions which regulate the use of discretionary powers in the Ghanaian 1993

\footnotetext{
' [1961] 2 Ghana Law Review (G.L.R.) pp. 523-535.

2 [1971] 1 G.L.R. pp. 138-152.
} 
Constitution and it looks at the choices we have to make from the various theories and the development of the administrative state in Ghana.

KEY WORDS: functionalism, Ghana, judicial review, law, liberalism

\section{INTRODUCTION}

In 1992, Ghana embarked on its fourth attempt at democratic constitutionalism. With our history of undemocratic government, and the grave abuses of fundamental human rights and democratic values that have taken place in the past in mind, the constitution took formal steps to protect and enhance cherished democratic values ${ }^{3}$.

One of the most significant powers available to the state is discretionary power ${ }^{+}$. Its misuse is perhaps the greatest threat to the consolidation of democratic values in our politics. It is not surprising that the constitution has taken special steps to regulate its use ${ }^{5}$. A citizen who believes that a public official has misused his discretionary power can seek review ${ }^{6}$ in the courts to test the legality of the use of the discretionary power?

There are however very serious difficulties in justifying judicial review of discretion. In this article, I shall review how modern English legal liberalism and functionalism, justify judicial review of discretion. Liberalism and functionalism are universal theories but the ones we discuss here have been developed within the English legal

\footnotetext{
${ }^{3}$ Chapter Five of the 1993 Constitution of the Republic of Ghana, on Fundamental Human Rights and Freedoms.

${ }^{4}$ The power of a person or of a body to choose amongst several possible means to reach an end. The range of options, however, is far from being unlimited. Laws and jurisprudence have put limits (red.).

${ }^{5}$ Article 296 of Chapter Twenty-Six of the 1993 Constitution.

${ }^{6}$ The so-called judicial review, the power of courts to check and strike down laws and administrative decisions (red.).

${ }^{7}$ Article 33 of Chapter 5 of the 1933 Constitution.
} 
system. Consequently, the theories and the discussions that follow have an English flavour. However, the problems that face the justification of judicial review of discretion are problems inherent in any democratic constitutional system which uses legal methods to control state power. Consequently, in the latter part of this paper, we shall discuss the problems as they relate to the Ghanaian legal and administrative system.

Theories are lenses through which we view reality. With the English theoretical analysis as the background, one of the other objectives of this paper will be to try to explain the theoretical basis of some judicial decisions about the control of discretion in our legal system. It is also hoped that lessons can be learnt from liberalism and functionalism about the choices available to us when we review discretionary powers within our legal system.

\section{THE IMPORTANCE OF ENGLISH LEGAL THEORY TO AFRICAN PUBLIC LAW}

Before we analyse these theories however, we need to provide a justification for this paper. Should English administrative law theories be of interest to an African Lawyer?

It is the position of the writer that understanding theories anywhere is important but understanding English legal doctrine is especially important for a number of reasons. First, as has already been stated, theories are the lenses through which we view reality. The problems to be addressed here, are inherent in any democratic constitutional system which uses the law as a means of controlling state power. The lessons we shall learn from theories in English law are bound to provide possible solutions to the problems we face in our system.

Another important reason why we must come to grips with these theoretical discussions is this; very soon, Ghanaians are going to have to take administrative law very seriously. As a result of structural adjustment policies, there are radical changes going on in the economic organization of the country. The state is likely to become less of a direct participant in the managing of the economy and more of a regulator of spheres of economic and social life as has occurred in many western countries. There is likely to be a proliferation of administrative agencies which would be given powers to regulate many areas of life. These powers are likely to be couched in discretionary terms. 
Interesting questions are bound to arise about the nature of these powers, the relationship between their use and the protection of individual rights. Ultimately, the answers we give will depend on our views of the fundamental relationship which we think ought to exist between the state and the individual. English constitutional theories try to answer these basic questions. These answers will help us, as we construct what we consider to be the appropriate relationship between the state and the individual.

\section{THE NATURE OF DISCRETIONARY POWERS}

When does an official have discretionary powers? For analytical purposes, we shall identify four conditions which have to be satisfied before we can say an official has discretionary powers. First he must have authority to choose between various options. Secondly, he must have power to create broad standards for achieving the chosen option. Thirdly, he must be able to vary the general standards in appropriate situations to achieve the chosen objective. Finally, there must be a recognition of his authority to create and vary the general standards within the legal and political framework ${ }^{8}$.

The core concept in discretion is choice. For discretion to exist, an official must be given power, within a broad framework, to either choose the end which is to be pursued, or if the end has already been determined, to choose the most appropriate means or standard to achieve the end. Galligan calls the process of creating standards 'individuation, and the standards created which serve as guides to decision-making, as 'principles of individuation'. Gifford calls them 'decision referents $^{10}$.

\footnotetext{
${ }^{8}$ D.J. Galligan, Discretionary Powers, Clarendon 1990 pp. 21-22, see also Grey J., 'Discretion in Administrative law' [1979] 17 Osgoode Hall Law Journal, (O.H.L.J.) pp. 107-132.

${ }^{9}$ D.J. Galligan, 'The Nature and Function of Policies within Discretionary Powers' [1976] Public Law, (P.L.) 324. See also H.L. Molot, The Self-Created Policy and Other Ways of Exercising Administrative Discretion' [1972] 18 L.J. McGill, pp. 310-342.

${ }^{10}$ D. Gifford, Decisions, Decisional Referents and Administrative Justice, [1972] 37 Law and Contemporary Problems, pp. 12-13.
} 
How much discretion an official has, will depend on the nature of the power and the recognition which other officials especially the courts give to his ability to choose. In the common law system, all exercise of official power must have a legal basis. The courts claim to have the final authority to decide the legality of any action".

\section{THE IMPORTANCE OF DISCRETION}

Why has discretion become such an important mechanism for exercising power within the public sphere in the modern state? It has been argued that there has been a fundamental change in the nature of modern society ${ }^{12}$. The demands that are being made on the modern state means that discretion, rather than rules are the better mechanism for exercising power. First, the state is called upon to intervene in many areas of social life. It is expected to solve problems in such diverse areas as employment, education, health care, environment and transport etc. The differences in these areas of concern means that the state has to take a flexible and non-rule approach to handling these issues. It cannot be assumed, for example, that methods which solve problems in health care can be used in to handle issues in education. Secondly, within an area of concern, the issues that have to be grappled with are inherently complex. For example, within transportation, the state has to deal with issues like pollution from gas emission, economic price for transport services, efficient use of transport facilities, anti-competitive behaviour etc. These complexities require expert knowledge and a flexible approach. This means that public officials have to be given discretionary powers.

\section{THE DANGERS OF DISCRETION}

Due to the element of personal choice inherent in discretion, certain criticisms have been made against its use in public affairs. For example, it has been argued that there is always the danger that discretionary powers will be used arbitrary.

\footnotetext{
${ }^{11}$ D.J. Galligan, Discretionary Powers, op. cit., 1990, p. 32.

${ }^{12}$ For example see R.M. Unger Law in Modern Society, Free Press, (1976), E. Kamenka and A.E.S Tay, 'Beyond Bourgeois Individualism: the Contemporary Crisis in Law and Legal Ideology' in: Feudalism, Capitalism and Beyond (ed.), Kamenka and Neale, Australian National U.P. (1978) p. 127. T. Prosser, 'Towards a Critical Public Law' [1982] 9 British Journal of Law and Society, pp. 14.
} 
Dicey, for example equated discretion with arbitrariness ${ }^{13}$ in recent times, K.C. Davis has argued that discretionary decisions can be arbitrary in the sense that officials may take decisions based on irrelevant factors ${ }^{14}$.

Another recurrent concern which has been raised by critics is the relationship between discretion and fairness. There are three different but connected conceptions of fairness, which are relevant here ${ }^{15}$. First, there is fairness in the substantive sense, when decisions have to be made about the fairness of the distribution of the benefits or burdens of society. Secondly, there is fairness in the procedural sense. Here questions are asked about the fairness of procedures through which important decisions affecting private and public interests are made. Finally, there is the issue of formal fairness. This is expressed in statements like 'treat like issues alike'. Discretionary decisions can be unfair when officials use their powers of personal assessment to act in ways which go against any of these conceptions of fairness.

Finally, there is the vital issue of guidance ${ }^{16}$. It has been argued that there is virtue in a stable relationship between the state and its citizens. This can be achieved through settled rules. This allows the citizen to know what is expected of him in advance and also allows him to plan his life according to known rules. Discretion falls short of this ideal because it allows public officials personal judgement on issues of public interest. The citizen cannot know in advance what decisions officials are going to take.

\section{THE BASIS OF JUDICIAL REVIEW}

One of the recurrent themes in political thought has been the need to control executive power so that it is not abused. One method for controlling executive power is through judicial review. The aim of judicial review is to ensure that public

\footnotetext{
${ }^{1.3}$ A.V. Dicey, The Law of the Constitution, London, 1961 edn. p. 188. See also Lord Hewart, The New Despotism, London, 1929, ch. iv.

${ }^{14}$ K.C. Davis, Discretionary Justice, Louisiana, 1969. See also J.L. Jowell, 'The Legal Control of Administrative Discretion', 1973 P.L. pp. 186-192, and D.J. Galligan, 'Arbitrariness and Formal Justice in Discretionary Decisions', in: D.J. Galligan (ed.), Essays in Legal Theory, Melbourne UP, 1984.

${ }^{15}$ D.J. Galligan, Discretionary Powers, op. cit., pp. 153-161.

${ }^{16}$ D.J. Galligan, ibid. pp. 161-163.
} 
officials stay within the law and do not abuse their powers ${ }^{17}$.

\section{PROBLEMS FACED IN JUSTIFYING JUDICIAL REVIEW OF DISCRETION}

As we have discussed there are dangers inherent in giving public officials discretionary powers and judicial review is one method through which administrative discretion is controlled. Yet, while the need to control administrative discretion may seem uncontroversial, the important question has always been whether judicial review is the most appropriate method for controlling such actions. The problems of the justification of the review of discretion resolve themselves into two broad questions.

\section{The Problem OF FUndamental VALUES}

There seem to be unresolveable tension between judicial review and democracy. On the one hand, in a democracy, the executive is elected by the majority, to implement its political programme. On the other hand, an unelected body like the courts can strike out the actions of the executive through judicial review. Are the courts not interfering with the democratic 'will' of the people when they strike out executive decisions in the course of reviewing administrative decisions? Are they not playing 'politics' through the backdoor?

A sympathiser of judicial review will not accept this criticism of judicial review. He will argue that, rather than undermining democracy, judicial review helps to consolidate it. Democracy, it is claimed, is not only about fulfilling the 'will' of the majority. It is also operating government within frameworks of norms and values: collective and individual human rights like participation and equality, justice and fairness. These values should not be subject to a majoritarian veto in a democracy. Consequently, when the courts strike out a decision because it is unfair or arbitrary or it diminishes an individual's rights, they are supporting democracy.

The values indicated above are the fundamental values, which give meaning to democracy. We shall call them the 'fundamental values'. One value, which we shall focus on in the discussion that follows, is 'individual rights' because it is the

\footnotetext{
${ }^{17}$ P.P. Craig, Administrative Law, Sweet and Maxwell, 1989 (sixth ed.) p. 22.
} 
quintessential liberal value. The question then becomes how to balance the various and fundamental values against the need for the state to carry out its responsibilities effectively. Should the courts always strike down any administrative decision because it goes against a fundamental value? Or should they balance these values with the object of reaching a reasonable result? Are there areas of political life, like national security and taxation, which are so 'politically oriented' that it is just not appropriate for the courts to intervene?

The position of the courts in protecting fundamental values in a democracy will be called 'the problem of fundamental values'. The difficult position of the courts when dealing with fundamental values, is captured succinctly by Hayfron Benjamin J. when he states that: The powers conferred on the High Court are wide in the extreme, but they seem to me to reflect the intention of the drafters that the courts should be the custodians and protectors of the liberties of the individual citizens of Ghana. It is a duty, which is at once onerous and honourable. In discharging these duties the courts must tread the narrow, humble but firm path between the Scylla of over-zealousness and the Charybdis of judicial timidity. Where the liberty of the citizen has been invaded they should by all means offer protection, but they should not try to find an invasion where none has occurred ${ }^{18}$.

\section{THE PROBLEM OF INSTITUTIONAL EXPERTISE}

Perhaps the greatest problem facing judicial review and especially the review of discretion is the problem of institutional expertise. As stated above, the multifarious problems of modern society can be adequately dealt with only in a legal framework, which allows the use of expert knowledge ${ }^{19}$. This may also require a flexible and a non rule approach to issues ${ }^{20}$. For example, a court, reviewing a claim of abuse of power, within the transport sector must understand how the industry operates before he can reach a proper conclusion. Unfortunately, judges have no expertise in the areas they review.

Upon what basis can it then reach a conclusion that a decision taken in the transport industry is unfair, or arbitrary? More generally, can an institution like the courts without any substantive expertise in the issues that they review, supervise the

\footnotetext{
${ }^{18}$ People's Popular Party v. AG. [1971] 1 Ghana Law Review (G.L.R.), p. 140.

${ }^{19}$ D.J. Galligan, Discretionary Powers, op. cit., pp. 72-84.

${ }^{20}$ Ibid.
} 
decisions of administrative bodies? We shall call this the problem of institutional expertise.

\section{ENGLISH ADMINISTRATIVE LAW THEORY}

We shall now attempt to see how modern English liberalism ${ }^{21}$ and functionalism ${ }^{22}$ try to answer these questions. Liberalism and functionalism have broadly opposing views about how judicial review can be justified ${ }^{23}$.

\section{LIBERAL THEORY}

What is the fundamental objective of liberalism? Why is judicial review important to a liberal and how can it be justified? What is a liberal's view of administrative discretion and how do they deal with the problems of fundamental values and institutional expertise?

To be able to do this we have to understand the ideal society from a liberal point of view. Generally, liberals place the protection of individual rights at the centre stage of political action. Community life is at its most ideal when there is a sphere of an individual's life, which is free from the encroachment of society. Sometimes this is described as 'negative liberty'.

\footnotetext{
${ }^{21}$ T.R.S. Allan, 'Legislative Supremacy and the Rule of Law': Democracy and Constitutionalism [1985] 44 Cambridge Law Journal (C.L.J.) pp. 111-143, Allan T.R.S., 'The Limits of Parliamentary Sovereignty' [1985] P.L. pp. 614-636. Jowell J. and Lester A. 'Beyond Wednesbury: Substantive Principles of Administrative Law' [1987] P.L. 368, For other examples, see also Williams G.D.S. 'Statute Law and Administrative Law' op. cit., 167-168. Zellick Graham, 'Government Beyond Law' P.L. pp. 283-308, Vincenzi C. "Aliens and Judicial Review of Immigration Law" [1985] P.L. 93114. Feldman D.,'Democracy, the Rule of Law and Judicial Review' in: [1990] 19 Federal Law Review 1 - 30. Feldman D., 'Public Law Values in the House of Lords' [1990] L.Q.R. 246, at 259.

${ }^{22}$ For examples, H.W. Arthurs, 'Rethinking Administrative Law: A Slightly Dicey Business' [1979] O.H.L.J., pp. 1-45, Galligan D.J., Discretionary Powers, op.cit., 1986., Ogus A.I. "Bureaucrats as Institutional Heroes", Oxford Journal of Legal Studies, (Ox. J.L.S.) 87, 309-315. A.I. Ogus, "Economics, Liberty and the Common Law", 15, J. Society of Public Teachers of Law, pp. 42-57. Ogus A.I. "Regulatory Law: some Lessons from the past" [1992] 12, Legal Studies pp. 1-19. Titmuss R.M. "Welfare 'Rights', Law and Discretion" Political Quarterly [1971] 42, pp. 113-132.

${ }^{23}$ For an interesting discussion of some of these issues see Loughlin Martin, Public Law and Political Theory, Clarendon, 1992. He however concentrates on 19 century theorists.
} 
In order to fully appreciate their views on the review of discretionary powers, we must distinguish between hard and soft liberalism. Hard liberals view official discretion with apprehension and only accept it as a necessary evil. Soft liberals recognize the importance of discretion in effective decision making and balance its advantages over its disadvantages. However, they would want the courts to have the final say on whether discretion has been used properly or not. And discretion has been abused if individual rights have not been given adequate protection without good reasons. Soft liberals thus make a moderate tilt in protecting liberal values at the expense of institutional expertise.

\section{A HARD LIBERAL FORMULATION}

In recent times, Allan has tried hardest to make coherent defence of liberalism in English public law ${ }^{24}$.

As a liberal, Allan places the protection of individual liberties at the heart of political life. He claims that the British constitution is based on two fundamental doctrines, parliamentary sovereignty and the doctrine of the rule of law. An accurate interpretation of the rule of law will show that the courts have the required role and power to protect fundamental liberal values.

Allan dislikes discretion and echoing the views of Dicey, argues that the rule of law doctrine holds that the law must protect citizens from the arbitrary will - discretion of public officials ${ }^{25}$. It demands that all state actions are justified in law ${ }^{26}$ and the courts must not sanction any departures from the ordinary law in favour of the state $^{27}$. Where there are doubts about the legality of any state actions, the presumption should always be in favour of the citizen ${ }^{28}$. Founded on the central importance of the rights of the individual, the rule of law provides a powerful breakwater against the diminution of individual rights by legislature ${ }^{29}$.

\footnotetext{
${ }^{24}$ The Limits of Parliamentary Sovereignty, op. cit., pp. 614-629.

25 Ibid. pp. 112-113.

${ }^{26} \mathrm{Ibid}$.

${ }^{27} \mathrm{Ibid}$.

${ }^{28}$ Ibid. p. 116.

${ }^{29}$ Ibid.
} 
What role should the courts play in judicial review? According to Allan, the justification of judicial review is that it protects the doctrine of the rule of law and thus individual rights and other liberal values - through statutory interpretation ${ }^{30}$ against the claims of the state. The courts must strike down any decision of the executive, which undermines individual rights. This is his solution to the problem of fundamental values.

There is however the danger that this hard liberal position is likely to lead to interference by the courts in the activities of the executive. This may encourage 'the Scylla of over-zealousness' - unnecessary judicial activism. In the modern state, many public actions involve some form of interference with individual rights. If the courts are to strike down any such interference in individual rights, modern government will be paralysed.

Allan does not directly address the problem of institutional expertise. But his answer would seem to be that the courts, in spite of the inexpert opinion, should strike down discretionary decisions if they interfere with individual rights. There are serious weaknesses in Allan's account here, because it fails to come to terms with the need for discretion in the modern administrative state. Discretionary powers are now an essential means of effective decision-making by public bodies. As societies become more complex, it is unlikely that general rules will be able to deal with all the different problems that arise in the such societies. Discretion is likely to be one avenue through which some of these problems can be solved. What is required is not rules which limit discretion but rules that would allow discretion to be used effectively.

\section{SOFT LIBERALISM - JOWELL AND LESTER}

The views of Jowell and Lester place them within the liberal tradition. They are however soft liberals. They value respect for human rights ${ }^{31}$ and think that the courts can provide a distinctive role for themselves in public law litigation by protecting such values.

They however have more sympathy with official discretion than hard liberals. In his early papers, Jowell recognized the strengths and weaknesses of official discretion.

\footnotetext{
${ }^{30}$ Ibid. pp. 620-621.

${ }^{31}$ J. Jowell and A. Lester, 'Beyond Wednesbury' op. cit., p. 368-369.
} 
He accepted the inevitability of discretion but argued that it had to be controlled by the courts. He balanced finely the advantages and disadvantages in using law to control administrative decisions ${ }^{32}$. He further argued that best form of decision making in the public domain was one that conformed with the 'ideal of due process $^{, 3.3}$. The 'ideal of due process' requires public bodies to give proper regard to the rights and interests of people who are affected by their decisions. This is achieved when a decision is taken on the basis of a reliable assessment of the facts. It also demands that all those who are likely to be affected by the decision of a public body should be allowed to participate in its proceedings. The 'ideal of due process' is bound to shape the use of official discretion so that arbitrariness is reduced.

Soft liberals also wish to promote the principles of good administration ${ }^{34}$. It is however important to recognize the very liberal basis of the principles of good administration. First, public action ought to pass the proportionality test ${ }^{35}$, which requires that the means used to achieve an objective should not be more onerous than is reasonably required ${ }^{36}$. The second principle of good administration demands legal certainty. Every one should be able to rely on the law as a guide to actions. No one should be punished for acts, which are not prohibited ${ }^{37}$. Finally, officials should be encouraged to act consistently. They should be bound by the representations they make to the public ${ }^{38}$.

We notice that administrative concerns are addressed although the emphasis is on protecting individual rights. It is possible to argue that both the 'ideal of due process' and the 'principles of good administration' are legalistic and are likely to encourage adjudicative procedures. This may not be useful to every administrative body. It is clear that Dicey's influence is very evident in soft liberalism.

\footnotetext{
${ }^{32}$ J. Jowell, 'The Legal Control of Administrative Discretion' op. cit. pp. 215-216.

${ }^{33} \mathrm{Ibid}$. 219, see also his general approval of Lord Denning's activism in: Jowell J., 'Administrative Law' in Lord Denning: The Judge and the Law (ed.), Jowell and Mc Auslan, pp. 209-212.

${ }^{34}$ 'Beyond Wednesbury' op. cit. p. 374.

35 J. Jowell and A Lester, 'Proportionality: Neither Novel Nor Dangerous' in New Directions in Judicial Review, ed. by Jowell and Oliver, Stevens, 1988, pp. 51-69.

36 'Beyond Wednesbury' op. cit. p. 375.

${ }^{37}$ Ibid. p. 377.

${ }^{38}$ Ibid.
} 
For a soft liberal the justification for judicial review is that it protects individual rights and liberties. Even though administrative discretion has to be exercised, it must operate within the democratic tradition. Decision-making must be effective but it must also protect liberal values.

\section{THE FUNCTIONALISTS REACTION}

Functionalists perceive issues in public law from the point of view of administrative bodies and not solely from the perspective of the individual. They accept that as a result of the changes in the nature of modern societies, the state will have to intervene in many aspects of social life if it is to deal with complex societal problems effectively. Functionalists recognize that the powers given to officials may be couched in discretionary terms. What they want to see is that discretion is exercised effectively.

Here we shall discuss the ideas of Arthurs ${ }^{39}$ and Galligan ${ }^{40}$ who are at different ends of the functionalist spectrum.

\section{HARD FUNCTIONALIST FORMULATION}

Arthurs is a hard functionalist and he provides the strongest critique of the liberal programme. His views on discretion and the role of the courts in the control of administrative actions are very interesting.

What are his attitudes towards the problem of fundamental values? According to Arthurs ${ }^{41}$, there are inherent dangers in the liberal view that the courts must have the final say in administrative decision-making by trying to assimilate administrative statutes into the common law. Liberal values cannot always take precedence over administrative effectiveness ${ }^{42}$. There is no reason why the ideal legal system should be a unitary one in which the common law should enjoy a preferred position compared to other laws.

\footnotetext{
${ }^{39}$ H.W. Arthurs, "Rethinking Administrative Law: A Slightly Dicey Business", op. cit. pp. 1-45.

${ }^{40}$ Discretionary Powers, op. cit. pp. 72-99.

${ }^{41}$ H.W. Arthurs, 'Rethinking Administrative Law', op. cit. p. 1.

${ }^{42}$ Ibid. p. 10.
} 
What is his attitude towards discretion? He disagrees with the liberal view of value basis of rules and discretion. Arthurs claims that Dicey's belief in the inherent goodness of general rules and his view that discretion is always arbitrary is a misplaced ideal. Discretion is an inevitable part of authority what the lawyer has to look for is" the optimum point on the rule-discretion scale" $"$. .

Modern public law therefore has to develop a distinctive jurisprudence that reflects the special objectives and techniques of specific areas of public life. Ultimately it must be ready to create different autonomous 'legal systems' in the political system dealing with specialized areas of public life $\mathrm{e}^{44}$.

What position does he take about the problem of institutional expertise? Arthurs thinks that because the courts have no substantive expertise in administrative decisions they should rarely be allowed to review administrative decisions. He rejects the distinction between substantial issues, which must be left to administration, and legal issues, which must be left to the courts. Arthurs argues that no such distinction exists. The relationship between law and substance is so close that when legal issues are left to the courts, they will inevitably substitute their inexpert opinion about substantial issues for that of administration. To give the courts the last word in the making of public policy would in effect give priority to legal values over administrative effectiveness ${ }^{45}$. Only when rationality and bona fide are lacking should constitutional standard be found to be violated ${ }^{46}$. The challenge is to infuse 'unordinary law' with the fundamental and transcendent values, which are prized in the legal system.

For Arthurs, judicial review can be justified only when it ensures rationality and bona fide. There is no other reason for the courts to interfere with administrative discretion.

\footnotetext{
${ }^{4.3}$ Ibid. p. 25.

${ }^{44}$ Ibid. p. 29.

${ }^{45}$ Ibid. p. 28.

${ }^{46}$ Ibid. p. 44.
} 


\section{CRITICISMS OF HARD FUNCTIONALISM}

Arthurs shows clearly some of the weaknesses in traditional administrative law theory. Unfortunately Arthurs goes to the other extreme and like Allan is unable to provide the important link between discretion, institutional expertise and democratic values. For example he does not tell us what the supposed transcendent values are and how they can be infused into the administrative system. He clearly rejects anything along Dicey's lines and if pushed is likely to reject the 'ideal of due process' as being too legalistic. The only option left would be exhortations to public bodies not to disrespect fundamental democratic values. But one wonders how effective this can be when public bodies know that it is very unlikely that there would be judicial review to correct maladministration. Arthurs approach to judicial review is likely to end up in judicial quietism.

\section{SOFT FUNCTIONALISM}

Galligan provides, to my mind, the best analysis of legal control of discretionary powers in English Law. He is a 'soft' functionalist. Galligan recognizes the importance of discretionary powers in dealing with the complex problems that face the modern state. He argues that because of the calls made on the state by citizens, the state is likely to be far more interventionistic than the liberals' ideal state. He thus argues for what he calls 'the public law model' as the best method for viewing issues within the public domain ${ }^{47}$.

How does Galligan view the problem of fundamental values? According to him, the state is expected to regulate diverse areas of modern life. Some of these objectives can be achieved only if there is a diminution of individual rights. Rights, thus lose their predominant position in this model. They are one of the many interests, which compete for the attention of the state.

Galligan does not believe that law ought to have a single objective - for example the protection of individual rights as postulated by hard liberals. While it will be difficult to imagine a legal system which does not aim at protecting rights and promoting a measure of stability and predictability in social life, there are no reasons why these should be the overwhelming objectives of law. Rather, the justification for judicial review lies in the fact that the courts can infuse administrative procedures and

${ }^{47}$ D.J. Galligan, Discretionary Powers, op. cit. pp. 86-99. Note particularly his preference for the public law model over the private law model. 
substantive decisions with the moral values that give meaning to democracy.

There are several competing values in the public law model but these have to adapt to the administrative procedures of public bodies. Galligan believes that these 'fundamental values' can be infused into administrative procedures if the courts intervene in public decision making, to maintain stability in legal relations, to encourage rationality in decision making and to promote fair procedures ${ }^{48}$. Stability of legal relations can be realized by insisting that public bodies use reasonably clear, settled, and binding standards when dealing with the public. The level of stability needed on a particular occasion will depend on the character of the administrative tribunal. Stability has to compete with other considerations like justice and efficiency.

There is also the need to encourage rational decision making in order to reduce arbitrariness. This means that objectives chosen by public bodies, or the means used to achieve them have to be based on good evidence ${ }^{49}$. Decisions made by public bodies must also serve the statutory purpose in an intelligent and reasonable manner. A requirement that public bodies provide reasons for the decisions they make, will be a means through which we can know the interpretation they have given to a statute. Disclosure of reasons is also likely to enhance rationality and provides respect and fairness to individuals.

On the problem of institutional expertise, Galligan would prefer that substantive decisions should be left to administration. The law's role primarily would be to provide an atmosphere, which will shape decision-making in a way that promotes rational decision making and protects fundamental values. So while substantial expertise is not interfered with, the infusion of fundamental values can prevent irrational and unreasonable decisions from being taken.

\section{SOME GHANAIAN CASES LAW ON DISCRETION}

We have now examined the various theoretical justifications for the review of discretion. With these theoretical 'spectacles' on, we shall now try to analyze some Ghanaian cases on the review of discretionary powers. What we shall attempt to do here is to understand the theory upon which the court decided a case. We shall also

\footnotetext{
${ }^{48}$ Ibid. p. 90 .

${ }^{49}$ Ibid. p. 266.
} 
try to assess the constitutional provisions for regulating discretionary powers in the light of liberalism and functionalism.

The cases we discuss here are by no means all the cases on legal review of discretion in Ghanaian law. They have been chosen because they are based on different theoretical positions and discussing them will show how the different theories work in practice.

In Re Akoto and 7 others ${ }^{50}$, the facts are that Akoto and seven other people were detained under section 2 of the Preventive Detention Act 1958. The Act gave the Governor-General discretion to detain anybody if he was satisfied that the actions of that person were prejudicial to the security of the state. The detainees' application for habeas corpus was rejected by the High Court and they appealed to the Supreme Court. One of the grounds of their appeal was that there was no basis for their detention and the court must inquire into the grounds of their detention to found out if the action taken - their detention - was necessary to safeguard the security of the state.

One of the first striking things about the detainees' argument is its soft liberal basis. We recall that Jowell stressed the importance of founding discretionary decisions on a correct assessment of facts. We should also note the introduction of something close to the soft liberal 'proportionality test' in the detainees' argument. The proportionality test requires that the means used to achieve an objective should not be more onerous than is reasonably required. The detainees wanted the courts to examine the facts of their situation to find out whether the action taken, - their detention - was 'proportional' to the need to safeguard national security.

Korsah C.J., stating the decision of the whole court, rejected these arguments. It is interesting to note also the 'hard' functionalist basis of his decision. He argued that on the basis of the English decision in Liversidge $v$ Anderson ${ }^{51}$, the courts had no authority to inquire into the facts upon which they had been detained. The statute gave the executive discretion and as long as there was nothing to suggest that they had acted in bad faith, the courts will not interfere with the exercize of this discretion. We must recall Arthurs famous statement that Only when rationality and bona fide are lacking should constitutional standard be found be violated ${ }^{52}$ Korsah C.

\footnotetext{
${ }^{50}[1961] 2$ G.L.R. pp. 523-535.

${ }^{51}$ [1942] A.C. pp. 206-283.

${ }^{52}$ H.W. Arthurs, 'Rethinking Administrative Law', op. cit. p. 44.
} 
J.'s ruling comes directly from 'hard' functionalist theory.

How would a 'hard' liberal have decided Re Akoto? Allan, we must recall, argued that the object of public law should be to protect the citizen against the arbitrary power of state officials. He also claimed that statutes must be interpreted restrictively to protect the citizen and where there are any doubts, it must be resolved in favour of the citizen. From a 'hard' liberal position the detention of Akoto and others was prima facie an affront to liberal values. The onus is thus on the Governor-General to prove that there are reasonable grounds for his decision. It is difficult to imagine how he can do this without providing some evidence to bolster his position. A 'hard' liberal is likely to reject Liversidge $\mathrm{v}$ Anderson as an unnecessary invasion into individual liberties.

In People's Popular Party v $\mathrm{AG}^{53}$, the question was whether the police had exercised their discretion properly by refusing the applicants, a registered political party, a permit to hold demonstrations in Accra during the second republic. Article 23 and 24 of the 1969 Constitution protected fundamental human rights of Ghanaians, including their freedom of movement, assembly and association. Under Act 58 as amended by Act 165 , the police had discretionary powers to give permits to people who wanted to hold public gatherings in the country. The use of discretionary powers under the 1969 constitution was subject to regulations similar to those imposed in the 1992 constitution ${ }^{54}$.

The applicants applied for a permit to demonstrate through the streets of Accra and around the French Embassy and British High Commission. They wanted to protest against the sale of arms by France and Britain to the apartheid regime in South Africa and the proposed dialogue between South Africa and the Ivory Coast. The Police had earlier given nationals of the UK in Ghana a permit to make a demonstration against the sale of arms by Britain to South Africa. The police refused the applicants a permit without giving any reasons for their decision.

The applicants challenged the decision of the police in the High Court, as an abuse of police discretion. Again, it is important to note the liberal basis of their argument. They claimed that their liberties were being interfered with by the refusal of the police to give them the permit.

\footnotetext{
${ }^{53}$ [1971] 1 G.L.R. pp. 138-152.

${ }^{54}$ We shall discuss these provisions in detail below.
} 
Hayfron Benjamin J. ruled that the police had abused their discretion. The basis of his decision is most interesting. It is a 'soft' liberal/functionalist argument. He makes a close connection between the provision of evidence and reasons and the protection of liberal values. There was no evidence that the police had been fair or candid in the exercise of their discretion. In order to prove to the courts that they were acting bona fide, the police had to give the reasons for their actions. They gave the applicants no reasons for their decision and the only reason they gave in court for their refusal to provide them with the permit was that a demonstration might infringe international law - if the demonstrators went to the foreign mission - and could damage Ghana's interests. However a permit can only be refused to an applicant if the gathering is likely to lead to a breach of the peace. Since no real reasons were given by the police for their refusal to give the applicant the permit, it would be concluded that they had not exercised their discretion properly.

Galligan stressed the importance of giving reasons as the basis of controlling administrative discretion. Jowell has also emphasized the need to base decisions on a reliable assessment of facts. We see strands of these arguments in HayfronBenjamin's judgement. It is interesting to see how he moves from the failure to give reasons to the position that discretion has been exercised improperly. Without adequate reasons, one cannot know the basis of the decision. If there are no basis for the decision then one can conclude that discretion has been abused. This will not be allowed to happen when it infringes a fundamental liberal value like liberty.

How would a 'hard' functionalist have decided this case? First, a functionalist is likely to be sympathetic to the police's position although he may not necessarily accept their argument. Even Arthurs, argued that rationality is an essential basis decision making in the public sphere. It is difficult to see how rationality can be satisfied without the provision of some evidence. However, it is the kind of evidence that is required to meet the constitutional standards which will separate a hard functionalist from a liberal. A functionalist will be satisfied by very basic evidence, while a liberal is likely look for incontrovertible evidence before he would conclude that the demonstration is likely to lead to a breach of the peace. A hard functionalist he would defer to the police because he would claim that he has not got the expertise to question the views of the police. 


\section{THE 1993 CONSTITUTION AND DISCRETIONARY POWERS}

Recognizing the importance and also the inherent dangers of discretionary powers, section 296 of the 1993 Constitution provides special steps to regulate the use of these powers. Section 296 requires that: Where in this Constitution or in any other law, discretionary power is vested in any person or authority -

(a) that discretionary power shall be deemed to imply a duty to be fair and candid;

(b) the exercise of the discretionary power shall not be arbitrary, capricious or biased either by resentment, prejudice or personal dislike and shall be in accordance with due process of law; and

(c) where the person or authority is not a judge or other judicial officer, there shall be published by constitutional instrument or statutory instrument, regulations that are not inconsistent with the provisions of this Constitution or that other law to govern the exercise of the discretionary power.

Let us recall the dangers of discretion. It was argued that discretion can be dangerous because it can be used in an unfair and an arbitrary manner. It also fails to provide sufficient guidance to the citizen so that he can plan his life according to the law. We can now see how the 1993 constitution attempts to deal with these dangers. Section 296 (a) requires that discretionary decisions be fair and candid. Section 296 (b) requires that decisions should not be taken in an arbitrary manner. Section 296 (c) requires the publication of regulations showing how a discretionary power will be exercised. The regulations are thus an attempt to guide citizens on how they should expect a discretionary power to be used. This deals with the problem of guidance.

It is likely that both functionalist and liberals will agree with these requirements. However, the more important point to notice - and this should be obvious from the discussion and case law - that there are bound to be differences among different theorists about whether a constitutional standard has been satisfied. For example both liberals and functionalist may agree that there is the need to have procedures which are fair. However a hard functionalist will argue for example that administrative bodies should be given the discretion to determine what procedures they will use and there is no reason why the procedures of different administrative bodies should be the same to satisfy the standard of fairness. Whether a procedure is fair or not should depend on the kind of decision that the body is supposed to take and not on some a priori concept of what is fair. A 'hard' liberal is likely taken a 
different position. For him, to call a procedure 'fair' means that it must satisfy a number of conditions - natural justice etc. The hard liberal will consider adjudication as the most ideal procedure. He is unlikely to accept a procedure which radically deviates from adjudicative procedures as 'fair'. It is clear that different outlooks will have an effect on their views as to whether the constitutional standards have been satisfied.

\section{ENGLISH LEGAL THEORY AND AFRICAN PUBLIC LAW}

We have seen the various theoretical approaches to the review of discretion in English law. In spite of the differences between English constitutional arrangements and ours, we have seen how these theories have relevance and can be applied to the problems that face the review of discretion in our legal system.

As the democracy and the administrative state develop, the problem of fundamental values will become a very lively one. Although our courts have the power to intervene to protect fundamental democratic values, we have yet to fully develop our own concept of democracy and the role that the judiciary has to play in protecting these values in our political system. Power in Africa, is still used in an extremely authoritarian manner, and there is still strong suspicion in government quarters about any attempt to reduce the power of state officials or protect liberal values. Our administrative bodies are likely to view issues mainly from the perspective of the state. If judicial review is to be effective, the courts will have to develop their theory of judicial intervention into substantive administrative decisions. The courts must provide strong reasons for intervening in issues in which they have no substantive expertise. Will administrative agencies be eager to protect their territory from judicial supervision? Liberals and functionalists give different answers to this question. Do we wish to perceive issues from a liberal or a functionalist perspective?

\section{CONCLUSION}

In this paper, we have looked at some of the reactions to the problems faced in justifying the judicial review of discretionary decisions in English law. We saw that 'hard' liberals and functionalists have gone to the extremes in their attempts either to protect democratic values and institutional expertise respectively. Soft liberals 
recognize the importance of discretion but still want a central role for the courts in controlling administrative behaviour. Soft functionalists see the importance of democratic values but emphasise the need to protect administration because of the problem of substantive expertise.

Our task now is to develop a theory that fits into both our democratic and development aspirations. 